\title{
Are using neutrophil-to-lymphocyte ratio and platelet parameters useful in predicting Short Bowel Syndrome in patients with mesenteric ischemia?
}

\section{Mezenter iskemili hastalarda nötrofil-|enfosit oranı ve trombosit parametrelerinin kullanılması Kısa Barsak Sendromunun gelişiminin öngörülmesinde faydalı mı?}

\author{
Sülleyman Koç, Sinan Soylu.
}

Department of General Surgery, Faculty of Medicine, Sivas Cumhuriyet University, Sivas, Turkey

Corresponding author: Sinan Soylu, MD, Department of General Surgery, Faculty of Medicine, Sivas Cumhuriyet University, Sivas, Turkey E-mail: soylu.sinan@hotmail.com

Received/Accepted: November 26, 2021 /November 30, 2021

Conflict of interest: There is not a conflict of interest.

\section{SUMMARY}

Objective: Acute mesenteric ischemia (AMI) is a potentially lifethreatening medical condition that results in bowel infarction and gangrene. It usually occurs over the age of 60 and is seen in both sexes at similar rates. Early diagnosis and treatment are the cornerstones in the treatment of AMI. Although different biochemical markers for AMI are used clinically, no specific laboratory test has been proven to identify the presence of ischemic or necrotic bowel. In this study, we aimed to evaluate Neutrophil/lymphocyte ratio (NLR), platelet/lymphocyte ratio (PLT/LYM), NLR/PLT, mean platelet volume-PLT ratio (MPV)/PLT, and MPV*NLR/PLT could be a useful tool for early prediction of the severity of AMI.

Method: We analyzed retrospectively records of 105 patients diagnosed with acute AMI who were operated on at our clinic. We investigated patient demographics, clinical symptoms, concomitant diseases, blood test results, and data regarding the surgical procedure performed and the resection's width. The patients were divided into two groups as short bowel syndrome (SBS) developing and non-developing.

Results: We enrolled a total of 105 AMI patients in this study. There was no significant difference between the rates of non-SBS and SBS in terms of age, gender, diabetes mellitus, and smoking status. WBC, NEU, LYM, and MPV were higher, and PLT was lower in the SBS group. There were no statistically significant differences in MPV/PLT between the two groups. The combined values of NLR, PLT, and MPV were also compared between non-SBS and SBS groups. According to our results, the means of NLR, PLT/LYM, NLR/PLT, MPV/NLR, and MPV*NLR/PLT variables were statistically significantly different between the two groups.

Conclusions: Our findings showed that NLR, NLR/PLT, MPV/PLT, $\mathrm{MPV}^{*} \mathrm{NLR}$, and MPV*NLR/PLT could be a relatively better tool for early prediction of the severity of AMI and SBS. Further studies have to be carried out to investigate the best parameter for predicting the severity or prognosis of AMI.
Süleyman Koç

Sinan Soylu

ORCID IDs of the authors:

S.K. 0000-0001-7794-4518

S.S. 0000-0002-3911-3227 
Keywords: Mesenteric ischemia, short bowel syndrome, neutrophil, platelet parameters.

\section{ÖZET}

Amaç: Akut mezenter iskemisi (AMI), barsak enfarktüsü ve kangren ile sonuçlanan, potansiyel olarak yaşamı tehdit eden, ciddi bir tıbbi durumdur. Genellikle 60 yaş üzerinde ortaya çıkar ve her iki cinsiyette de benzer oranlarda görülür. AMI tedavisinde erken tanı ve tedavi temel taşlardır. AMI için farklı biyokimyasal belirteçler klinik olarak kullanılsa da, iskemik veya nekrotik bağırsak varlığını tanımlayan spesifik bir laboratuvar testi henüz kanıtlanamamıştır. Bu çalışmada Nötrofil/lenfosit oran1 (NLR), trombosit/lenfosit oran1 (PLT/LYM), NLR/PLT, ortalama trombosit hacmi-PLT (MPV)/PLT ve MPV*NLR/PLT oranlarının AMI'nin ciddiyetinin erken tahmininde yararlı araçlar olabileceğini değerlendirmeyi amaçladık.

Yöntem: Kliniğimizde opere edilen akut AMİ tanısı almış 105 hastanın kayıtları geriye dönük olarak incelendi. Hastaların demografisi, klinik semptomlar, eşlik eden hastalıklar, kan testi sonuçları ve uygulanan cerrahi prosedür ve rezeksiyon genişliği ile ilgili verilerini araştırdık. Hastalar kısa barsak sendromu (SBS) gelişen ve gelişmeyen olarak iki gruba ayrıldı. Bulgular: Bu çalıșmaya toplam 105 AMI hastasını dahil ettik. SBS olmayan ve SBS olanların oranları arasında yaş, cinsiyet, diabetes mellitus ve sigara içme durumu açısından anlamlı bir fark yoktu. SBS grubunda WBC, NEU, LYM ve MPV daha yüksek, PLT daha düşüktü. İki grup arasında MPV/PLT'de istatistiksel olarak anlamlı fark yoktu. NLR, PLT ve MPV'nin birleşik değerleri de SBS olmayan ve SBS grupları arasında karşılaştırma yapmak için kullanıldı. Sonuçlarımıza göre, NLR, PLT/LYM, NLR/PLT, MPV/NLR ve MPV*NLR/PLT değișkenlerinin ortalamaları iki grup arasında istatistiksel olarak anlamlı derecede farkliydi.

Sonuç: Bulgularımız NLR, NLR/PLT, MPV/PLT, MPV*NLR ve MPV*NLR/PLT'nin AMI ve SBS şiddetinin erken tahmin edilmesi için nispeten daha iyi bir araç olabileceğini gösterdi. AMI'nin ciddiyetini veya prognozunu tahmin etmek için en iyi parametreyi araştırmak için daha ileri çalışmalar yapılmalıdır.

Anahtar sözcükler: Mezenter iskemisi, kisa barsak sendromu, nötrofil, trombosit parametreleri.

\section{INTRODUCTION}

Acute mesenteric ischemia (AMI), inadequate blood flow to the bowel, is a potentially lifethreatening medical condition that results in bowel infarction and gangrene. It usually occurs over the age of 60 and is seen in both sexes at similar rates 1. In previous studies, it has been reported that $90 \%$ of AMIs are due to arterial and $10 \%$ to venous causes. Arterial causes are divided into two as occlusive and non-occlusive ${ }^{2}$.

It is difficult for most clinicians to diagnose AMI in the first place, as these patients often have severe abdominal pain disproportionate to the physical examination findings ${ }^{3}$. During a good background check; Postprandial abdominal pain, a history of weight loss, and atrial fibrillation may suggest AMI ${ }^{3,4}$. Since the symptoms of AMI are not specific and cause high mortality and morbidity when its treatment is delayed, it continues to be an interdisciplinary problem in clinical areas such as Emergency, Radiology, General Surgery, Vascular Surgery, and Gastroenterology 5 . It will be understood that early diagnosis and treatment are the cornerstones in the treatment of AMI since mortality will decrease from $50-60 \%$ to $10-20 \%$ when diagnosed and treated within the first 6 hours ${ }^{3}$. The main complications of AMI are ischemia due to circulatory disorders in the small intestine and colon, necrosis, Short bowel syndrome (SBS), infection due to perforation, and sepsis ${ }^{6,7}$.
SBS is a complex disease resulting from an extensive resection of the small bowel (jejunum, ileum, ileocecal valve) and/or partially or completely of the colon. The main factors affecting survival in these patients include the length of the remaining intestine and its anatomy and function, age, comorbidity, presence of chronic bowel disease, and the team's experience in the postoperative follow-up ${ }^{8}$. In other words, SBS is defined as the inability of the remaining intestine to maintain nutritional, fluid, and electrolyte balance during a normal, healthy diet, depending on the combination of the factors mentioned above ${ }^{9}$.

The presence of intestinal loops dilatation, free intraperitoneal air, portal venous gas, and pneumatosis intestinalis findings on computed tomography (CT) are evaluated as signs in favor of the diagnosis of AMI ${ }^{6}$. However, it is very important to decide on laparotomy before the patient develops septicemia and irreversible shock. On the other hand, there is a vital need for diagnostic tools such as accurate radiology and blood tests to avoid unnecessary negative laparotomy.

Although different biochemical markers for AMI are used clinically, no specific laboratory test has been proven to identify the presence of ischemic or necrotic bowel ${ }^{2}$. Blood count devices used in many laboratories today can test the complete blood cell count (CBC), the white blood cells count (WBC), 
neutrophil, lymphocyte (LYM), platelet counts (PLT) parameters, such as mean platelet volume (MPV), platelet distribution width (PDW), and plateletcrit (PCT). Thanks to these basic and inexpensive tests, we can perform not only to distinguish the causes of hematologic diseases such as leukocyte diseases, platelet-related diseases, and anemia but also for suspected ischemic events ${ }^{10}$. Platelets have both roles in the normal hemostatic process and abnormal conditions such as bleeding and thrombosis ${ }^{11}$. Neutrophils are one of the main components of the immune system and represent the adaptive immune system ${ }^{12,13}$. In many diseases, WBC, neutrophil, lymphocyte, PLT, and MPV values and their ratios are used as inflammatory indicators. Neutrophil/lymphocyte ratio (NLR), platelet/lymphocyte ratio (PLT/LYM), NLR/PLT, MPV/PLT, and MPV*NLR/PLT are among the most important of these indicators and have been studied recently to determine the severity of some diseases ${ }^{10,12,13}$.

In this study, we aimed to evaluate whether these parameters or combinations of them could be a useful tool for early prediction of the severity of AMI and its deadly complication, short bowel syndrome.

\section{MATERIAL AND METHODS}

\section{Patients}

We analyzed retrospectively records of all patients diagnosed with acute AMI who were hospitalized between January 1, 2011, and October 31, 2021, at our clinic. The study protocol was approved by the Sivas Cumhuriyet University Non-Invasive Clinical Studies Ethics Committee (Decision no. 2021-10/21). While conducting this study, the principles of the Declaration of Helsinki were taken as a guide. We investigated patient demographics, clinical symptoms, concomitant diseases, blood test results, and data regarding the surgical procedure performed and the resection's width. The patients were divided into two groups as SBS developing and non-developing. All patients with peritoneal irritation findings such as abdominal pain, tenderness, and nausea, AMI were diagnosed preoperatively based on clinical examination findings, blood test results, angio computed tomography (angio-CT)) of the abdominal vasculature were referred for urgent laparotomy. Patients with symptoms of chronic mesenteric ischemia and who were not operated were excluded from this study.

\section{Treatment}

The majority of our patients were cases of advanced age and in the late period, and interventional radiological procedures could not be performed. Necrotic small bowel segments and colon sections were resected during laparotomy. If there was no intestinal content in the surgical area and the intestinal loops were not excessively edematous, anastomosis was performed following resection. However, when the presence of necrotic material was abundant, and infection in the abdomen, end ileostomy or end colostomy was performed following resection. After the surgical procedure, all patients were initially admitted to the intensive care unit for close follow-up (multipleorgan function support) and treatment (antibiotic therapy, fluid, and nutrition therapy).

\section{Groups and definitions of patients}

Patients with a small part of the ileum and/or part of colon necrosis, those who had resection without ileostomy or colostomy, and those who do not need parenteral nutrition and special diet at follow-up were defined as a non-SBS group. Patients with bowel perforation or extensive bowel necrosis involving jejunum, long part of the ileum and/or part of the colon, those who had ileostomy or colostomy in addition to resection, and who do need parenteral nutrition and special diet at followup were defined as SBS group.

\section{Statistical Analyses}

The statistical software tool SPSS 23.0 was used to make statistical comparisons (SPSS Inc., Chicago, IL, USA). Kolmogorov Smirnov and Shapiro Wilk's tests were used to test whether the variables fit the normal distribution. The Mann Whitney U test was performed to examine the statistical significance of the difference between the group means after it was found that the variables utilized were not suitable for a normal distribution. To compare categorical variables, the chi-squared test was utilized. With the Spearman, Correlation analysis size and direction of the relationships between the variables were determined using correlation analysis. The effect size of the variables was determined using logistic regression analysis. The established model was used to calculate the risk sizes of the variables.

\section{RESULTS}

We enrolled a total of 105 AMI patients in this study. $64(60.95 \%)$ of the patients were men, and $41(39.04 \%)$ of women. There was no significant difference between the rates of non-SBS and SBS in both women and men $(\mathrm{P}=0.453)$. The mean age of the patients in the non-SBS and SBS groups were $67.14( \pm 11.54)$ years and $73.24( \pm 12.83)$ years, respectively. Among the patients' comorbidities, diabetes mellitus 60(57.1\%) and 
smoking 54(51.4\%) were the most frequent. There was no significant difference between the rates of non-SBS and SBS in terms of diabetes mellitus and smoking status. Pearson Chi-Square analysis was applied to determine the relationship between categorical variables and SBS. According to the analysis results, it was concluded that there was no statistically significant relationship between the variables of gender, smoking, and DM on the development of SBS (Table 1).

Table 1: Demographic features of patients at presentation

\begin{tabular}{|l|c|c|c|}
\hline & $\begin{array}{c}\text { Non-SBS } \\
(\mathrm{N}=29)\end{array}$ & $\begin{array}{c}\text { SBS } \\
(\mathrm{N}=76)\end{array}$ & $p$ \\
\hline Age (y) & $67.14 \pm 11.54$ & $73.24 \pm 12.83$ & 0.000 \\
\hline Gender (n) & $13(44.8)$ & $28(36.8)$ & 0.453 \\
Female & $16(55.2)$ & $48(63.2)$ & \\
Male & $12(41.4)$ & & 0.203 \\
\hline Smoking status (n) & $17(44.8)$ & $42(55.2)$ & \\
Yes & $19(65.5)$ & $34(44.8)$ & 0.284 \\
No & $10(34.5)$ & $41(53.9)$ & \\
\hline DM (n) & $35(46.1)$ & \\
Yes & No & & \\
\hline
\end{tabular}

Non-SBS; Short-bowel syndrome, SBS; Short-bowel syndrome, DM; Diabetes mellitus. Results were given as mean \pm standard deviation. *P values indicate differences between non-SBS and SBS. P $<0.05$ was defined as statistically significant.

Table 2: Comparison of laboratory parameters of patients in non-SBS and SBS groups.

\begin{tabular}{|l|l|l|l|}
\hline & \multicolumn{1}{|c|}{$\begin{array}{c}\text { Non-SBS } \\
(\mathrm{N}=29)\end{array}$} & \multicolumn{1}{c|}{$\begin{array}{c}\text { SBS } \\
(\mathrm{N}=76)\end{array}$} & $P$ \\
\hline HGB $(\mathrm{g} / \mathrm{dL})$ & $14.19 \pm 2.30$ & $14.22 \pm 2.71$ & 0.596 \\
\hline HCT $(\%)$ & $42,96 \pm 7,02$ & $42,92 \pm 7,84$ & 0,547 \\
\hline WBC $(\times 109 / \mathrm{L})$ & $19,0 \pm 4,23$ & $25,11 \pm 5,92$ & 0,013 \\
\hline NEU( $\times 109 / \mathrm{L})$ & $17,00 \pm 4,21$ & $23,29 \pm 5,74$ & 0,003 \\
\hline LYM $(\times 109 / \mathrm{L})$ & $1,26 \pm 0,86$ & $2,47 \pm 12,53$ & 0,000 \\
\hline PLT $\times 109 / \mathrm{L})$ & $271,96 \pm 92,71$ & $254,97 \pm 66,37$ & 0,004 \\
\hline MPV $(\mathrm{fL})$ & $7,19 \pm 1,69$ & $9,89 \pm 1,67$ & 0,003 \\
\hline NLR & $25,77 \pm 26,19$ & $31,83 \pm 23,02$ & 0,000 \\
\hline PLT/LYM & $412,28 \pm 511,40$ & $357,66 \pm 268,47$ & 0,000 \\
\hline NLR/PLT & $0,10 \pm 0,11$ & $0,13 \pm 0,09$ & 0,000 \\
\hline MPV/PLT & $0,03 \pm 0,01$ & $0,04 \pm 0,01$ & 0,196 \\
\hline MPV*NLR & $180,52 \pm 178,43$ & $317,83 \pm 254,79$ & 0,000 \\
\hline MPV*NLR/PLT & $0,71 \pm 0,72$ & $1,30 \pm 1,01$ & 0,000 \\
\hline
\end{tabular}

Non-SBS; Short-bowel syndrome, SBS; Short-bowel syndrome, HGB; Hemoglobin, HCT; Hematocrite, WBC; White blood cells, NEU; Neutrophil, LYM; Lymphocytes, PLT; Platelet, MPV; Mean platelet volume, NLR; Neutrophil-to-lymphocyte ratio. Results were given as mean \pm standard deviation. 
Kolmogorov Smirnov and Shapiro Wilk tests were performed to test whether there was a difference between the means of the relevant variables. A significance level of less than 0.5 in both tests was interpreted as the relevant variable did not conform to the normal distribution. Median values, statistics, and $\mathrm{p}$ values of these variables are as in Table 2. There was no significant difference in HGB and HCT between the two groups $(\mathrm{P}=0.596$ and 0.547 , respectively). WBC, NEU, LYM, and MPV were higher, and PLT was lower in the SBS group. There were no statistically significant differences in MPV/PLT between the two groups $(\mathrm{P}=0.196)$. On the other hand, values of NLR, PLT/LYM, NLR/PLT, MPV/NLR, and MPV*NLR/ PLT were obtained by combining NLR, PLT, and MPV. These combined values were also used to compare between non-SBS and SBS groups. According to the Mann Whitney $\mathrm{U}$ test results, the means of NLR, PLT/LYM, NLR/PLT, MPV/NLR, and MPV*NLR/PLT variables were statistically significantly different between the two groups.

\section{DISCUSSION}

AMI had traditionally been defined as inadequate blood flow to the bowel. This disease is frequently a potentially life-threatening medical condition that results in bowel necrosis, and it often occurs in old ages ${ }^{1,14,15}$. It still continues to be a serious disease today because its clinical complaints are nonspecific and have very serious consequences if the diagnosis is delayed. Therefore, if there is an objective laboratory tool for risk stratification in emergencies that would consider AMI, it would be helpful in many ways, such as early diagnosis and treatment, thus lowering morbidity and mortality ${ }^{5}$.

Of the platelet parameters, PLT is a well-known parameter for any patient, reflecting the stable balance of platelets in a way that reflects thrombopoiesis, platelet consumption, and aging. MPV, which stands for mean platelet volume, reflects platelet function and activation ${ }^{10}$. Previous studies found a close relationship between MPV value and ischemic cardiovascular diseases and certain clinical states such as diabetes, hypercholesterolemia, and colorectal cancer ${ }^{10,16}$.

On the other hand, NLR is a value that can be calculated by simply dividing the neutrophil by lymphocyte and is accepted as an indicator of systemic inflammation. The NLR value was significantly higher in patients with an ischemic attack than in the normal group in previous studies. Likewise, a correlation was found between PLT, MPV, and NLR values and the severity of the acute ischemic attack. In addition, since MPV is associated with platelet activation and severity, and PLT value is an index reflecting platelet consumption, dividing MPV and NLR by PLT value may have a potential power in predicting disease severity ${ }^{10,12,13,17}$. In our study, there was no significant difference between the two groups in MPV/PLT values, while NLR/PLT values were found to be higher in the SBS group than in the non-SBS group.

To our knowledge, there have been few studies investigating the association of values obtained by the combination of some parameters such as LYM, NLR MPV, and PLT with the initial of AMI ${ }^{18}$. Our findings showed that NLR, PLT/LYM, NLR/PLT, MPV/NLR, and MPV*NLR/PLT could be used as a relatively good tool for predicting severity at the time of admission than other parameters.

In this study, SBS inevitably occurred in the postoperative period in 76 of 105 patients who presented with AMI clinic because of poor clinical, laboratory, radiological, and intestinal and colonic appearance during laparotomy; SBS did not develop in 26 patients because the findings as mentioned above were relatively mild. Laboratory parameters such as NLR, PLT/LYM, NLR/PLT, MPV/NLR, and MPV*NLR/PLT were found to be significantly higher, especially in parallel with the development of SBS. We evaluated only whether each parameter could be a useful tool for early prediction of the severity of AMI and its serious complication SBS. In additional studies, it may also be helpful to use these parameters for an indication, as mentioned above, with more patients.

Our study has several limitations, as follows. Because the patient population included in the study was relatively small, further studies would be required. The selection bias in this study was that it only included patients who were operated on in a single center and were not compared with the control group. However, due to AMI's low incidence and clinical course, it seems very difficult to plan and conduct randomized clinical trials involving this patient group. In this study, the etiology of AMI was roughly determined since there was no precise information about the history of the patients, so it could not reflect the detailed clinical causes.

\section{CONCLUSION}

Our findings showed that NLR, PLT/LYM, NLR/PLT, MPV*NLR, and MPV*NLR/PLT could be a relatively better tool for early prediction of the severity of AMI and SBS. Further studies 
have to be carried out to investigate the best parameter for predicting the severity or prognosis of AMI.

\section{REFERENCES}

1. Emile SH, Khan SM, Barsoum SH. Correction to: Predictors of bowel necrosis in patients with acute mesenteric ischemia: systematic review and meta-analysis. Updates Surg. 2020 Dec;72(4):1297-1298. doi: 10.1007/s13304020-00863-x.

2. Miller ED, Fisher JL, Haglund KE, Grecula JC, Xu-Welliver M, Bertino EM, He K, Shields PG, Carbone DP, Williams TM, Otterson GA, Bazan JG. Identifying patterns of care for elderly patients with non-surgically treated stage III non-small cell lung cancer: an analysis of the national cancer database. Radiat Oncol. 2018 October 5;13(1):196. doi: 10.1186/s13014-018-1142-7.

3. Luther B, Mamopoulos A, Lehmann C, Klar E. The Ongoing Challenge of Acute Mesenteric Ischemia. Visc Med. 2018 Jul;34(3):217-223. doi: 10.1159/000490318.

4. Park WM, Gloviczki P, Cherry KJ Jr, Hallett JW Jr, Bower TC, Panneton JM, Schleck C, Ilstrup D, Harmsen WS, Noel AA. Contemporary management of acute mesenteric ischemia: Factors associated with survival. J Vasc Surg. 2002 Mar;35(3):445-52. doi: 10.1067/mva.2002.120373.

5. Bala M, Kashuk J, Moore EE, Kluger Y, Biffl W, Gomes CA, Ben-Ishay O, Rubinstein C, Balogh ZJ, Civil I, Coccolini F, Leppaniemi A, Peitzman A, Ansaloni L, Sugrue M, Sartelli M, Di Saverio S, Fraga GP, Catena F. Acute mesenteric ischemia: guidelines of the World Society of Emergency Surgery. World J Emerg Surg. 2017 August 7;12:38. doi: 10.1186/s13017-017-0150-5.

6. Copin P, Zins M, Nuzzo A, Purcell Y, Beranger-Gibert S, Maggiori L, Corcos $\mathrm{O}$, Vilgrain V, Ronot M. Acute mesenteric ischemia: A critical role for the radiologist. Diagn Interv Imaging. 2018 Mar;99(3):123134. doi: 10.1016/j.diii.2018.01.004.

7. Kärkkäinen JM, Acosta S. Acute mesenteric ischemia (Part II) - Vascular and endovascular surgical approaches. Best Pract Res Clin Gastroenterol. 2017 Feb;31(1):27-38. doi: 10.1016/j.bpg.2016.11.003.

8. Le Beyec J, Billiauws L, Bado A, Joly F, Le Gall M. Short Bowel Syndrome: A Paradigm for Intestinal Adaptation to Nutrition? Annu
Rev Nutr. 2020 Sep 23;40:299-321. doi: 10.1146/annurev-nutr-011720-122203.

9. O'Keefe SJ, Buchman AL, Fishbein TM, Jeejeebhoy KN, Jeppesen PB, Shaffer J. Short bowel syndrome and intestinal failure: consensus definitions and overview. Clin Gastroenterol Hepatol. 2006 Jan;4(1):6-10. doi: 10.1016/j.cgh.2005.10.002.

10. Lim HH, Jeong IH, An GD, Woo KS, Kim KH, Kim JM, Cha JK, Han JY. Early prediction of severity in acute ischemic stroke and transient ischemic attack using platelet parameters and neutrophil-to-lymphocyte ratio. J Clin Lab Anal. 2019 Mar;33(3):e22714. doi: 10.1002/jcla.22714

11. Lim HH, Jeong IH, An GD, Woo KS, Kim KH, Kim JM, Cha JK, Han JY. Early prediction of severity in acute ischemic stroke and transient ischemic attack using platelet parameters and neutrophil-to-lymphocyte ratio. J Clin Lab Anal. 2019 Mar;33(3):e22714. doi: 10.1002/jcla.22714.

12. Ak1l E, Ak1l MA, Varol S, Özdemir HH, Yücel Y, Arslan D, Akyüz A, Alan S. Echocardiographic epicardial fat thickness and neutrophil to lymphocyte ratio are novel inflammatory predictors of cerebral ischemic stroke. J Stroke Cerebrovasc Dis. 2014 Oct;23(9):2328-34. doi: 10.1016/j.jstrokecerebrovasdis.2014.04.028

13. Celikbilek A, Ismailogullari S, Zararsiz G. Neutrophil to lymphocyte ratio predicts poor prognosis in ischemic cerebrovascular disease. J Clin Lab Anal. 2014 Jan;28(1):27-31. doi: 10.1002/jcla.21639.

14. Merle C, Lepouse C, De Garine A, Frayssinet N, Leymarie F, Leon A, Jolly D. Surgery for mesenteric infarction: prognostic factors associated with early death within 72 hours. J Cardiothorac Vasc Anesth. 2004 Dec;18(6):734-41. doi: 10.1053/j.jvca.2004.08.011.

15. Huang HH, Chang YC, Yen DH, Kao WF, Chen JD, Wang LM, Huang CI, Lee CH. Clinical factors and outcomes in patients with acute mesenteric ischemia in the emergency department. J Chin Med Assoc. 2005 Jul;68(7):299-306. doi: 10.1016/S17264901(09)70165-0.

16. Stojkovic Lalosevic M, Pavlovic Markovic A, Stankovic S, Stojkovic M, Dimitrijevic I, Radoman Vujacic I, Lalic D, Milovanovic T, Dumic I, Krivokapic Z. Combined Diagnostic Efficacy of Neutrophil-to-Lymphocyte Ratio 
(NLR), Platelet-to-Lymphocyte Ratio (PLR), and Mean Platelet Volume (MPV) as Biomarkers of Systemic Inflammation in the Diagnosis of Colorectal Cancer. Dis Markers. 2019 January 17;2019:6036979. doi: $10.1155 / 2019 / 6036979$.

17. Daly ME. Determinants of platelet count in humans. Haematologica. 2011 Jan;96(1):10-3. doi: 10.3324/haematol.2010.035287.
18. Türkoğlu A, Gül M, Oğuz A, Bozdağ Z, Ülger BV, Yilmaz A, Aldemir M. Mean platelet volume: is it a predictive parameter in diagnosis of acute mesenteric ischemia? Int Surg. 2015 May;100(5):962-5. doi: 10.9738/INTSURG-D14-00268.1. 